\title{
THE HGALĀL INDUSTRY FROM A SHARI'AH PERSPECTIVE
}

\author{
Mohammad Hashim Kamali*
}

\begin{abstract}
The haläl industry is still in its early stages of development, and efforts to chart the way forward in compliance with Islamic principles are desirable and necessary. As with Islamic banking in the early years, this industry has also been largely driven by market demands and realities. It would be advisable to enrich the achievements of the haläl industry with research efforts that advance a better understanding of Islamic principles and the scientific knowledge relevant to our concerns. The article begins with a review of evidence in the Qur'ān and hadith on the halāl or mubāhn, and then proceeds to address the harām. The later part of the article covers the reprehensible (makrūh) and the recommendable (mandūb) respectively, as well as figh and the relationship between Islam and science.
\end{abstract}

\section{Understanding the Parameters of Ḥalāl and Ḥarām}

Muslim jurists have discussed the source evidence and formulated guidelines to regulate the application of these value indicators to dietary substances. Haläl and harām are not black and white categories. There is a grey area known as al-shubhät, or doubtful matters that may occasionally call for fresh juristic enquiry and ijtihād as to their permissibility or otherwise. Fiqh works provide details over almost every known variety of animal, bird, insect, and so on.

\section{The Permissible (Halāl, also Mubāḥ, and Jā'iz)}

Of the three Arabic words that appear in this heading, halāl and its derivatives occur more frequently in the Qur'ān and hadìth whereas fiqh literature is more inclined to employ mubāh and jā'iz. ${ }^{1}$ Halāl may be defined as an act, object or conduct over which the individual has freedom of choice and its exercise does not carry either a reward or a punishment. Halāl may have been identified by explicit evidence in the shari 'ah or by reference to the presumption of permissibility (ibāhah) as explained below.

* Prof. Dr Mohammad Hashim Kamali is the Chairman and CEO of IAIS Malaysia. This article is an upgraded version of a paper presented at the World Halāl Forum 'Sustained Development Through Investment and Integration’ (Kuala Lumpur, 12 May 2008). 
The scale of five values that is known to Islamic jurisprudence, namely the obligatory, recommended, permissible, reprehensible, and forbidden (wäjib, mandūb, mubāh, makrūh and harām, respectively) does not occur in the Qur'ān or hadīth. The Qur'ān may thus use the word halāl or its derivatives directly, or declare that 'there is no sin', 'no liability', 'no blame', or that 'God will not take you to task' for such and such, all of which imply permissibility. This can also be said of the makrūh and the mandūb, for which a variety of expressions are employed in the Qur'ān and hadīth. Thus, when we read in these sources, expressions such as 'God does not love' such and such, or when an act is described as 'an abomination', 'disliked', 'misguided' and so forth, it would indicate a makrūh, and the opposite of such expressions may also imply a mandū $b .^{2}$

The textual guidelines on halāl suggest that no restrictions should be imposed on the basic freedom of the individual and that the scope of prohibitions should not go beyond what has been determined by the text. The permissible, or halāl, has consequently been left open. The Qur'ān declares: “This day all things good and pure have been made lawful to you" (5:6); and "O mankind, eat of that which is lawful and wholesome in the earth" (2:168 and 172); and then again: "O ye who believe! Forbid not the good things that Allah has made halāl for you" (5:87). This outlook on halāl has enabled jurists to formulate guidelines, such as the following legal maxim: "permissibility is the basic norm in all things unless there be evidence to establish a prohibition". ${ }^{3}$ The principle of permissibility (ibāhah) also means that freedom is the normative position of the shari ' $a h$ with regard to foodstuffs, animals on land and in the sea, customary matters, commercial transactions and contracts. All are permissible in the absence of a clear prohibition.

Muslim jurists have also held that any textual evidence which overrules the presumption of permissibility must be decisive in both meaning and transmission simply because a harām cannot be established on the basis of doubtful evidence, such as a weak hadìth, or a qur'ānic verse that does not convey a clear meaning - in which case the subject would be governed by the norm of permissibility. ${ }^{4}$ The two main exceptions to $i b \bar{a} h a h$ are devotional matters ( 'ibādāt), and sexual intercourse between a man and a woman who are not married. The basic presumption here is that acts of devotion ( $i b \bar{a} d \bar{a} t$ ) must be validated by a clear text, otherwise they are presumed to be forbidden.

The Mālikis are the most liberal with regard to the permissibility of foodstuffs from animal sources that may have been classified under makrūh or even forbidden by the other schools. The Shāfi is, Hanafis, and the Ja 'faris or Twelver Shi ites are moderate whereas the Hanbalis tend to be restrictive. The Mālikis permit all varieties of land and sea animals and birds, including the stray animals (jallalah) that feed on filth, and also birds of prey as well as ants, worms, and beetles to be permissible for human consumption. Most other schools have declared them as makrūh if not harām. ${ }^{5}$ 
There are three types of halāl/mubāḥ. First, mubāḥ that does not entail any harm to the individual whether he or she acts on it or not, such as travelling, hunting or walking in the fresh air; second, mubāh whose commission does not harm the individual although it is essentially forbidden. This may include the consumption of carrion to save one's life. ${ }^{6}$ The third variety of mubāh refers to conduct that Islam prohibited but which was committed before the advent of Islam or, with reference to converts, before they embraced the religion. For instance, wine-drinking was not prohibited until the Prophet's migration to Medina, hence it fell under mubāh until the revelation of the Qur'ān verse which finally declared it forbidden (5:90). ${ }^{7}$ As al-Ghazālī (d. 1111) explains, it is incorrect to apply mubāh to the acts of a child, an insane person, or an animal, nor would it be correct to call the acts of God mubāh . Acts and events that took place prior to the advent of Islam are not to be called mubāh either.

Mubāh has again been subdivided into three types:

1. Acts that are mubāh for the individual but recommendable (mandūb) for the community as a whole. Eating certain foods, such as vegetarian food, beef, mutton, and so on, is mubāh for the individual, but it is mandūb for the community as a whole to have them available in the marketplace.

2. Acts that are $m u b \bar{a} h$ for the individual but obligatory (wājib) for the community as a whole. Under normal circumstances, eating, drinking and marriage may be mubāh for the individual, but to ensure their availability is a $w \overline{a j i b}$ for the community and its leadership. Similarly, it is $m u b a \bar{h}$ for the individual to choose his line of work and profession, but the community as a whole is under obligation to ensure the survival of certain types of industry and trade.

3. Acts that are mubāh on an occasional basis but forbidden if pursued regularly. For example, an occasional use of harsh words on one's child is mubāh but forbidden if practised all the time, and makrūh if practised frequently. ${ }^{8}$

\section{The Prohibited (Harām)}

Harām (also known as maḩzūr) may be defined as "all that which the Lawgiver $\left(a l-s h \bar{a} r i^{\prime}\right)$ has prohibited in definitive terms, and its perpetrator is liable to a punishment in this world or the Hereafter". Harām is thus an act, object, or conduct that is forbidden by evidence in the Qur'ān or hadīth. Committing harām is punishable and omitting it is rewarded. This is the position of the majority of the legal schools of Islam (madhăhib). For Hanafis, if the source evidence in question is anything less than definitive in respect of both authenticity and meaning, the harām is downgraded to makrūh tạ̣rīmī (makrūh close to harām) and no longer harām in the full sense. The two resemble one another in that committing either 
is punishable and omitting rewarded, but they differ in so far as a wilful denial of the harām incurs infidelity, which is not the case with regard to makrūh tahrimmī. ${ }^{9}$

The Qur'ān provides the primary proof in respect of harām, as the text itself declares: "He (God) has explained to you in detail what is forbidden to you" (6:119), which means that a vague and inconclusive text is not enough to establish a harām. With regard to prohibited food, for instance, the Qur'ān has specified ten items, namely "carrion, blood, the flesh of swine, the animal slaughtered in any name other than Allah's, the animal which has either been strangled, killed by blows, has died of a fall, or by goring or devoured by a beast of prey" all of which are harām $(5: 3) .{ }^{10}$ The subject also occurs in two other verses which actually summarise the ten items into four (cf. 6:145 and 2:172) as the last six items are actually included in the category of carrion. Wine drinking has also been declared forbidden (5:90). This is the sum total of clear prohibitions found in the Qur'ān. As for the rest, it is ordained: "And do not utter falsehoods by letting your tongues declare: this is haläl and that is harām, thus fabricating lies against God" (16:116). All other foodstuffs, animals of land and sea, harmful or unclean substances and so on, which are discussed in the fiqh manuals are subject to disagreement due mainly to the different perceptions of jurists concerning 'the grounds of harām' as I elaborate below. Although the hadith plays a role in determining what is haräm, the scope is fairly limited. Salmān al-Fārisī narrated that the Prophet was asked a question about the wild ass, quails and curdled milk, and he gave the following response: "Halāl is that which God has permitted in His Book, and haräm is that which God has prohibited in His Book. As for what He has chosen to remain silent about, it is exonerated." "II Since there was no particular text in the Qur'ān on the three items in question, they were consequently declared to be halāl. There is thus little scope for anyone else, including the jurist, the mujtahid (one who exercises ijtihād), the mufti and the government authorities in the determination of harām. There is some flexibility for the head of state to prohibit what is a makrūh or make mandūb the subject of an obligatory command in order to realise a manifest mașlahah (public interest), or prevent a manifest mafsadah (corruption, harm).

Harām is divided into two types: (a) harām for its own sake (harām li-dhātih), such as theft and murder, carrion, bloodshed, and so on, which are forbidden for their inherent enormity; and (b) harām due to the presence of an extraneous factor (harām li-ghayrih), such as a sale which is used as a disguise for securing usury $\left(r i b \bar{a}^{\prime}\right)$. A consequence of this distinction is that harām for its own sake is null and void (bātil) ab initio, whereas violation of a harām li-ghayrih renders its subject matter into a fāsid (voidable) but not null and void, and a transaction over it may, according to the Hanafis, fulfil some of its legal consequences. Most schools do not recognise fāsid as a separate category and would subsume the violations in question all under bätil. Harām for its own sake does not become permissible save in cases 
of dire necessity (darūrah), such as imminent death from starvation. Harām due to extraneous factors becomes permissible in cases of manifest need and when it prevents hardship (haraj). According to a legal maxim of fiqh "the means toward harām also partakes in harām". ${ }^{12}$ If theft and murder are harām, the means toward procuring them are also harām, and if pig meat is harām, trading, processing, exporting and promoting it also partake in the same.

The rules of harām are applied equally to all. It would thus be unacceptable, outside the situations of dire necessity, to make concessions in favour of particular individuals and groups, localities, climatic conditions and the like. Muslims may not relax the rules of harām in their dealings with non-Muslims either, nor would it be valid to make concessions on the ground of common practice of something which is harām. ${ }^{13}$ Recourse to legal stratagems (hiyal) that seek to procure harām under a different guise or name is also forbidden. ${ }^{14}$ Good intentions do not justify the harām either: in response to the question whether a harām act can be combined with one that is intended to seek closeness (qurbah) to God - such as giving stolen food, or the proceeds of rib $\bar{a}$ ', in charity - it is stated that the harām overrides and suppresses the qurbah. The halāl and harām are not always self-evident nor clearly identified in the sources, and a grey area persists between them that falls under the rubric of doubtful matters (al-shubhät) which I shall separately address. But before that, I propose to explore the grounds of harām (asbāb al-tahrīm) especially with reference to foodstuffs.

\section{The Grounds of Ḥarām}

Muslim jurists have identified four grounds of harām in foodstuffs: manifest harm, intoxication, filth / natural repulsiveness, and encroachment on the rights of others:

\section{Manifest harm (darar)}

Poisonous plants and flowers, snakes, scorpions, poisonous fish and arsenics are included in this category. Poison is forbidden for human consumption absolutely, according to the majority of the leading schools of Islamic law. However, the Mālikī and Hanbali schools have held that some quantities of it may be used in medicine and treatment of disease. ${ }^{15}$ This addition is generally agreeable as exceptional uses of poison are also covered under the subject of necessity (darürah). Harmful substances also include objects that may be harmful, even if not poisonous, such as eating mud, charcoal, harmful plants and animals etc. The Shāfi is hold that these may not be harām for someone who is not harmed by them, whereas the Hanbalis classify these objects under the category of reprehensible (makrūh). Added to this is the proviso that identifying the harm in an object is not always self-evident and may need expert opinion. ${ }^{16}$ 


\section{Intoxication}

Intoxicants of all kind, including alcohol and all varieties of narcotics, whether liquid or solid are forbidden on the basis of clear textual mandates of the Qur'ān (5:90), and the hadīth which declares that "every intoxicant is like khamr [wine] and all khamr is harām". ${ }^{17}$ Since this is a harām for its own sake (harām li-dhātih), it is prohibited regardless of the quantity used, whether by itself or mixed with other substances and diluted, unless the mixture is such that it alters the nature of the substance and it is no longer intoxicant - such as when wine turns into vinegar. Alcohol may not be used in medicine at first recourse, as per general agreement of the leading schools, although they all allow for situations of absolute necessity when, for example, it is known for certain that alcohol or its derivatives provide a cure to a disease and no other alternative can be found. ${ }^{18}$

\section{Filth, impurity and natural revulsion (najas, rijs, khaba 'ith, mustaqdharāt)}

These are either identified as carrion, spilt blood, pig meat (Qur'ān 6:145), or when people of sound nature consider them as such. It may be solid, liquid, animate or inanimate. Khabith (pl. khabä'ith, revolting, impure), being the antonym of tayyib (pure, clean) is a degree lower than both the najas and rijs. Khabä' $i t h$ accordingly subsumes predatory animals and birds as well as certain insects, such as lice and worms. They may not be najas in themselves, but they are subsumed, nevertheless, under the qur'ānic prohibition of al-khabä'ith (7:157). Some substances are declared unclean because of the repulsion they invoke even if they are not filthy in themselves, such as human spit, mucous, sweat and semen, all of which are clean, but are declared non-halāl for consumption on grounds of their natural repulsion.

\section{Unlawful acquisition}

Forbidden foodstuffs and beverages also include unlawfully acquired property, such as stolen or usurped food and objects obtained through gambling, bribery, fraud and other unlawful means that are harām in the view of the sharì $a h$. This is the purport of the qur'ānic address to the believers to "devour not one another's properties wrongfully, unless it be through trading by your mutual consent" (4:29). ${ }^{19}$ An exception is granted in this connection to certain individuals, such as one's parent and guardian, the waqf administrator, and one compelled by dire need and threat of starvation.

\section{The 'Grey Areas': Doubtful Matters (al-Shubhāt, Mashbūh, Mashkūk)}

These are the intervening (and often undetermined) matters that fall between halāl and the harām. Doubts may arise due mainly to two factors: Either the source 
evidence of the shari 'ah is not free from doubt, or else its application to a particular subject or case is uncertain.

The Qur'ān (3:7) itself has confirmed that some parts of it are inherently doubtful or mutashabihāt. The Prophet has further acknowledged this in a long hadìth to the effect that haläl and haräm had been made clear from one another, but that "in between them there are the doubtful matters which are not known to most people whether they are halāl or harām. One who avoids them for the purity of one's religion and honour would have saved oneself [...]." ${ }^{20}$ To avoid doubt, and to make an effort to stay clear of it, is thus conducive to piety and one's good name and reputation. This much is indicated in the wording of the hadith, which speaks of absolution (istibra $\bar{a}^{\prime}$ ), and the course of action suggested in it indicates caution over doubtful matters.

The advice so conveyed partakes, in al-Qaraḍāwī's view, of the nature of "obstructing the means to an evil end (sadd al-dharā'i), which is informed by certain insights into the health of one's personality and character $[\ldots]$ ". ${ }^{21}$ In yet another hadīth, Muslims are instructed to "abandon that which is doubtful to you in favour of that which is clear of doubt". ${ }^{22}$ Today, doubts arise about factory farming where animal remains are fed to other animals, and the use of hormones and antibiotics also present difficulties in verifying whether the meat is haläl. Factory practices may also fail the test of compatibility with the Islamic principle of compassion. Definitive answers to these questions need to be informed by scientific evidence. The frequent incidence of BSE ('mad-cow disease') in the West ${ }^{23}$ has also raised questions about feeding and rearing methods and the wholesomeness of meat. These are genuine doubts that merit investigation and research. Yet I find somewhat restrictive the view that "Muslims are required to eat meat that is not only halāl but also tayyib." ${ }^{24}$ The question posed here is whether Muslims should go a step beyond haläl in their choice of food - something that the figh tradition does not stipulate. This demanding position can also amount to inflicting hardship on ordinary consumers who are not sufficiently informed about the food varieties they buy in the marketplace. According to a legal maxim of fiqh, "when the haläl and harām are mixed up, the harām prevails". ${ }^{25}$ In other words, when available evidence can imply both permissibility and prohibition, the latter prevails.

Confusion may thus arise due to the existence of two divergent hadìth reports, or two conflicting analogies: One is prohibitive, the other permissive, and the former prevails over the latter. The doubt that arises may be genuine (haqi $\bar{q} \bar{l})$, such as ambiguity in the actual wording of a hadīth, or it may be relative and metaphorical (ida $\bar{a} \bar{l}$, and $m a j \bar{a} z \bar{\imath}$ ), and doubt arises in their application to a particular case. In all of these, an opportunity may arise for fresh interpretation and ijtiha $\bar{d}$, which should be attempted and an effort made to secure that which is in the public interest and mașlahah. Thus in cases of confusion between lawfully slaughtered meat and 
carrion, the prohibitive position prevails and consumption is consequently not recommended. Similarly in the case of confusion arising between revenues from rib $\bar{a}$ ' and from a lawful sale, one should exercise caution on the side of avoidance. In the case of the hybrid breeding of animals, such as between a horse and a mule, the issue should be excluded from the halāl range. Most jurists would, however, take the mother's side as the stronger indicator of permissibility: If the mother is halāl, the issue is also considered halāl.

Should there be a mixture of two varieties of food, one haläl and the other harām, two situations may initially arise: Either the separation of the two parts is not feasible, such as when wine, blood or urine is mixed with water - then harām prevails over haläl; or else the two parts can be separated, as when an insect or unclean substance falls on solidified butter - the object itself and its surrounding parts are removed and the rest becomes haläl. However, if the mixture is of very small quantities that are hardly detectable and establishment of complete purity is not devoid of hardship, such as the remains of small amounts of alcohol in cooking utensils in big hotels, the doubt in them may be overlooked but avoidance is preferable. ${ }^{26}$

\section{The Reprehensible (Makrūh)}

Makrūh according to the majority of leading schools refers to an act, object, or conduct that should be avoided but whose perpetrator is not liable to punishment and does not incur moral blame. The Hanafis are in agreement with the majority position in respect of only one of the two varieties of makrūh, namely makrūh for the sake of purity (makrūh tanzìh $\bar{\imath}$ ), but not with regard to what they classify as makrūh tahrīmī (makrūh closer to harām), which does entail moral blame but not punishment. The madhāhib are in agreement that one who avoids makrüh merits praise and gains closeness to God. ${ }^{27}$ Makrūh is the lowest degree of prohibition and, in this sense, it is used as a convenient category for matters that fall between the haläl and harām (that is, matters that are definitely discouraged but where the evidence to establish them as harām is less than certain). The Hanafĩ category of makrūh tanzīhī is subsumed under mubāh by the majority.

According to the Hanafis, an act is haräm when it is decreed in definitive terms, but when there is an element of weakness in the prohibitive language of the Qur'ān or hadìth, the matter falls under makrūh tahrīmī. For example, it is makrūh tahrīmī to make an offer of betrothal to a woman who is already betrothed to another man. The reason for this is that the hadīth proscribing this is a solitary $(\bar{a} h \underline{a} \bar{d})$ hadìth, which is not altogether devoid of doubt in respect of authenticity. ${ }^{28}$ There is much disagreement among jurists about makrūh in foodstuffs and other substances for human consumption, but most include rotten meat that develops an offensive smell, 
water of a well in the midst of a graveyard, and unsupervised cattle and poultry that feed on impurities and filth such that changes of taste and smell in them may be detectable. The relevant hadiths also include the milk of such animals. ${ }^{29}$ This impurity is, however, removed when animals are kept away from their dirty habitats for a number of days (three for poultry, four for sheep and goats, and ten for camels and cows). The preferred position of the majority of schools on this issue, however, departs from these specifications and merely advises isolation until the offensive signs and smells are no longer present. ${ }^{30}$ Certain organs of lawfully slaughtered and $h a l a \bar{l}$ animals have also been declared non-halāl. These include blood, the phallus, testicles, vagina, glands, gall bladder and bile, which are considered by the Hanafis to be makrūh tahrīmī due to the fact that the prohibitory hadīth text on them is a solitary hadīth that is not free of all doubt. ${ }^{31}$ The subject also falls under the Qur'ān text that "he (the Prophet) forbids to them (Muslims) the khabä'ith" (7:157). But this verse is also a manifest text (zähir) which is in the nature of probability. It is not certain, in other words, that the six items were actually meant to be included under the khabä'ith. The prohibitive view also holds these organs to be abhorrent to people of sound nature (al-taba' 'i ' al-salimah). ${ }^{32}$ The other three schools are less restrictive, but their preferred position also considers the organs in question to be makrūh. ${ }^{33}$ As for the use of rennet (minfahah) from the stomach of cattle for use in fermenting and processing cheese, if it is taken from a lawfully slaughtered animal, it is halāl by consensus; but if taken from carrion, it is non- $h a l a \bar{l} l$ according to the majority, but halāl according to the Hanafis on the ground of an analogy they draw between this and the milk of such an animal. ${ }^{34}$ Other instances of makrūh to be noted in conjunction with the rituals of slaughter include rough handling (such as dragging the animal by its feet), abandoning the tasmiyah (i.e. reciting the name God) according to the Shāfi is and Mālikis, slaughter in front of another animal, the use of bones and stones as cutting tools, cutting or skinning the animal before the complete exit of life, not facing the qiblah, and citing the name of Muhammad next to that of Allah. The Mālikis do not stipulate facing the qiblah as a requirement of slaughter due to the absence of textual evidence on this. The basis of this they say is a weak analogy that is drawn between the obligatory prayer (saläh) and slaughter, which are altogether two different things. ${ }^{35}$

\section{The Recommended (Mandūb)}

Mandūb (also known as sunnah, mustahab, nafl) denotes an act or conduct that the sharī $a h$ has recommended, but which is not binding. To comply with the mandūb earns one spiritual reward but no punishment is imposed for its neglect. Mandī $b$ is the opposite of makrūh, and this means that avoidance of makrūh amounts to

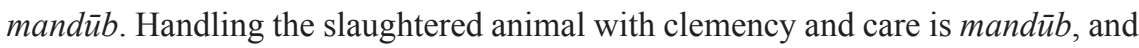


rough handling is makrūh. To set up a charitable endowment (waqf), attend to the sick, and honour one's neighbour and one's guest are all recommended. If the mandūb is an act which the Prophet has performed on some occasions but omitted on others, it is called sunnah, which is also of two types: It is emphatic sunnah (sunnah mu'akkadah, also known as sunnat al-hudā) if the Prophet has performed it regularly, or which he has strongly recommended, such as attending the obligatory prayers (salāh), and calling out the call for prayer (adhān) preceding it. To perform an act of merit, such as offering two units of sunnah prior to the obligatory zuhr or 'așr prayers, or being generous in charity above the level of the obligatory alms tax (zakāh) are examples of supererogatory sunnah, or sunnah ghayr mu'akkadah. The schools of law have employed a variety of other expressions for mandīb, such as tatawwu', faḍilah, ihsān and raghä'ib with finer distinctions that often consist of sound advice and cultural refinement. ${ }^{36}$

\section{Custom and Science: Determining the Lawful and the Unlawful}

\section{Requirements of a Valid Slaughter}

The rituals of a valid slaughter and its accompanying requirements of cleanliness are fairly well-known to the halāl industry, and the prevailing practices are also deemed to be compliant with sharī ah guidelines. The foregoing discussion indicated some of the features of a valid slaughter and what may be regarded to be mandī $b$ or makrūh. The discussion that follows highlights some of the additional requirements of a valid slaughter, and also some disputed issues:

1. The element of intention: A lawful slaughter occurs only when it is with the intention for a valid use, and not merely to kill an animal for the sake of killing. Hence, a slaughter without such an intention is non-halāl.

2. Reciting the tasmiyah (i.e. the name of God) at the time of slaughter is obligatory (wäjib) according to the majority of madhāhib, whereas the Shāfi is consider it to be recommended (mandūb) and abandoning it as makrūh. All schools would, on the other hand, exonerate from these requirements the case of genuine forgetfulness without intentional preclusion. It is noteworthy that the Qur'ān stipulated tasmiyah for slaughter in contrast to the pre-Islamic Arabian practice of reciting the names of deities. It is also instructive to note that mankind is not naturally entitled to take the life of an animal unless it is with the permission of the Creator, and tasmiyah is an affirmation and acknowledgement of that. Richard Foltz draws the following conclusions from his review of the evidence: "First, the tradition takes the relationship between humans and other animal species quite seriously. Second, animals are seen as having feelings and interests 
of their own. And third, the overriding ethos enjoined upon humans is one of compassionate consideration." ${ }^{\prime 37}$

3. Ritual slaughter is allowed by a person who is a Muslim or follower of a revealed scripture, including Christians and Jews. The Qur'ān has thus affirmed that "the food of the ahl al-kitäb" - such as the Christians and Jews - is haläl for Muslims, and vice versa (5:5). ${ }^{38}$ The food and slaughter of the ahl al-kitāb is haläl to us generally even if they omit the tasmiyah, or even recite the name of Jesus Christ or Moses. Some Muslim jurists have disputed this last position, but since the qur'ānic permission is conveyed in unqualified terms, it is halāl for Muslims to consume their food and their slaughter. ${ }^{39}$

4. According to a general consensus of the leading madhāhib, severance is required of the four vital passages in the slaughter of animals, namely the trachea, oesophagus and jugular veins. Some minor disagreements have arisen to the effect that slaughter occurs even if the oesophagus is not cut, though it is recommended to sever the four sections all at once.

The following slaughter practices are recommended (mandūb):

- recitation of both tasmiyah and takbir (i.e. Allähu akbar);

- completion of slaughter in daylight so as to prevent error in the correct procedures;

- facing the qiblah, although the Mālikī school does not require this;

- except for the camel (which requires $n a h r$, as opposed to dhabh, in standing position with a left leg tied up), all animals should rest on the left side with their heads lifted upwards; and

- clemency to the animal and avoidance of rough handling. ${ }^{40}$

The following are considered reprehensible (makrūh) in the slaughter rituals:

- slaughter by a disabled person;

- abandoning the tasmiyah according to those who do not consider it obligatory, namely the Shāfi is and some Mālikis;

- facing the animal in a direction other than the qiblah;

- $n a h r$ of the cattle and dhabh of the camel; the normal method is in the reverse order.

- inflicting pain on the animal such as by severing the head completely or breaking the skull, dragging the animal, and slaughter from the back of the neck; and

- slaughter by a dull and unsuitable knife. ${ }^{41}$ 
Certain aspects of the distinction between the makrūh and harām are not always accurately stated. Note for instance that some individual writers have labelled as harām that which may actually amount to no more than makrūh. Some of the halāl procedural guidelines also stipulate ritual cleansing for leather materials made from animals that have not undergone halāl slaughtering. This is evidently not a requirement of the renowned hadìth, recorded by Muslim and Abū Dawud, which provides: "when any hide is tanned, it is purified". ${ }^{42}$ The ruling of this hadith is general ( 'àmm) and unqualified, hence it includes "all hides even of the dog and the pig. This is the position of the Zāhirī school, also recorded by Abū Yūsuf, the disciple of Abū Hanīfah, and it is preferred by al-Shawkān̄̄."43 Furthermore, it is quite obvious from our perusal of the relevant rules that the shari 'ah prohibition of carrion is confined to eating and does not extend to the use of its hide, horns, bones and hair, all of which are permitted. They are valuable $m \bar{a} l$, and if they could be put to a good use, they should not be wasted. ${ }^{44}$

\section{The Role of Custom ('Urf)}

General custom ( 'urf, ' $\bar{a} d a h$ ) is a recognised source of law and judgment in Islam. It is defined as "recurrent practices that are acceptable to people of sound nature". ${ }^{45}$ To constitute a valid basis of judgment, custom must be sound and reasonable and must not contravene a clear text or principle of the sharī $a h$. Custom is rejected if it is in conflict with a clear injunction of the shari 'ah, such as some tribal practices that deny women their rights of inheritance. In the event, however, of a partial conflict between a text and custom, the latter may qualify or specify the former. A valid ruling of custom often takes precedence over the normal rules, or the ruling of analogy (qiyass). This is because custom represents the people's convenience, and adopting it is often tantamount to removal of hardship, which is one of the expressed purposes of the shari 'ah. It is commonly acknowledged that a great deal of the fiqh rules and the rulings of $i j t i h \bar{a} d$ have taken their cues from the prevailing practices of the time. The role of custom is evidently recognised in the evaluation of the mandūb and makrūh in foodstuffs, which often correspond with what is approved or disapproved by the people of sound nature (often referred to as the ahl al- 'urf). The law may recognise some food as halāl but may not be liked by the people and may thus to all intents and purposes be relegated to the category of makrūh, or else that a $m u b \bar{a} h$ is elevated to the level of mandūb by the people's preference for it. When this is the case, then according to a leading maxim of fiqh: "Custom is the basis of judgment (al- 'Édât $t^{u}$ muhakkamat ${ }^{u n}$ ). " ${ }^{\prime 46}$ For instance, custom determines the question of whether or not an object is regarded as valuable property, or $m \bar{a} l$, that carries market value. For instance, honey bees and silk worms were at one time not regarded to be $m \bar{a} l$ but were later determined to qualify as $m \bar{a} l$ by the people's usage and acceptance of them as such, and a fatwa was accordingly issued in its support. 
Custom is, moreover, changeable with the advancement of science and technology, which often set in place new practices that may soon gain wide recognition and acceptance. People's tastes regarding foodstuffs are also affected by the media and advertisements and so forth. New practices take hold among people as and when they prove to be convenient, which is often reflected in their lifestyle and food varieties. All of this is likely to carry the seal of sharì 'ah approval if no principles have been contravened. Furthermore, people's approval and disapproval also play a role in the determination of what may be regarded as a compelling necessity (darürah).

\section{Islam and Science}

Islam and science are too broad and also too important to be treated in a short passage intended merely to identify what bearings they have on the halāl and harām in Islam. However, the first question that arises concerns the basic premise of these concepts: halāl and harām are evidently not determined by reference only to human reason or scientific knowledge, but a combination of these and the guidance mainly of divine revelation (wahy). Worship matters ('ibadat) are normally determined by the shari ${ }^{\prime}$ ah independently of scientific evidence, and this could also be said of a limited number of dietary restrictions Islam has imposed - even though there may be some scientific justification for them. Having said this, Islam is on the whole receptive to scientific evidence. If one considers the Islamic prohibition of carrion, spilt blood, alcohol and pig meat for consumption, most of these, if not all, can perhaps stand the test of scientific knowledge. Scientific rationality essentially confines reality to the data of sense perception, which precludes metaphysical reality and revealed knowledge as well as some of the nonphysical sides of the human existence (such as reducing intelligence to the level of neural chemistry where mental and behavioural phenomena are understood merely as manifestations of physical processes).

Islamic juristic thought recognises various levels of distinctions with a view to addressing temporal reality within its own perimeters. For instance, the distinction between shari ${ }^{\prime} a h$ and fiqh did not exist during the first century of the advent of Islam, and the triple division of the sharì ah into theology (kalām), morality (akhlāq) and figh (practical rulings) also developed at a later stage. A certain level of separation was thus recognised between theoretical theology and the practical rules of concern to the daily life and conduct of the individual. In the sphere of the applied sciences and the benefits they can bring to humanity, Islam maintains an open outlook. Thus it is not only acceptable but may even rank as mașlahah (public interest) to employ scientific knowledge for the good of the people. Muslims have consequently not seen their faith as a hindrance to scientific knowledge. They have, on the contrary, made significant contributions to the advancement of science. The Prophet advocated beneficial knowledge ( $a l$ - 'ilm al-nafi') that responds to people's legitimate needs, and accordingly instructed his followers to seek knowledge "even if it be in China". 
Thus it is not difficult to see that Islam accepts beneficial scientific knowledge from any source.

The robust advocacy of 'ilm in the Qur'ān, its open acceptance of knowledge gained through sense perception and observation, and its encouragement of us to investigate the world around us, all in all depict a basic alignment and convergence of interests between Islam and science, and not otherwise. Islamic philosophy that mainly studies purposes, as against science, which mainly studies causes, sees objects and events as signs ( $\bar{a} y \bar{a} t)$ of the Divine presence in the universe. Faith is understood by Muslims not as a limitation on science but as its vista for enrichment and perfection. Thinking Muslims should therefore work to vindicate the symbiotic relation of faith and reason, of knowledge and science, and advance a broader understanding of these and other civilisational objectives of Islam.

Consider, for instance, the use of stunning and the thoracic stick procedures, and whether they are acceptable from the sharì' $a h$ viewpoint. Questions may arise as to how stunning and thoracic stick practices were originally introduced: For reasons of industry convenience, for animal welfare, or both. Although the sharì ah favours the smooth flow of lawful trade in the marketplace even at the expense of some compromise on other grounds, it does not favour measures that would present a threat to its higher values. Any decision that a sharì $a h$ specialist makes on stunning and thoracic stick issues, without the required scientific input, is bound to be based on externalities and assumptions that would be less than adequate - given the sensitivity of the issues and extensive application of the decisions in question. This also serves to illustrate the symbiotic relationship that we envisage between fiqh and scientific knowledge.

\section{Conclusion and Recommendations}

Since the ummah is a unity in faith, its numerous component parts and the 57 OIC member countries must remain open to learning from one another and must appreciate the respective mores and cultural diversities within the wider unity of Islamic civilisation. If Islam can be characterised as diversity within unity, of sound $i k h t i l a \bar{f} f$ within the purview of tawhìd, it is largely due to the unifying influence of the Qur'ān, the exemplary teachings of the Prophet Muhammad, and a degree of consensus on basic values. The ummah also upholds a moral code of spiritual and legal dimensions that is grounded in the dual notions of halāl and harām. Haläl food and haläl trading and finance are among the tangible manifestations of the shared values that give the ummah its distinctive characteristics. Compared to $i k h t i l a \bar{f}$, tawhìd is a much more prominent feature of Islam. Since uniformity and standardisation bear greater affinity with tawhìd, to promote standardisation in the halāl industry is not only desirable but also eminently feasible. The purpose 
would naturally be better served if one aims at the common denominators of values, cultures and customs that can appeal to greater uniformity in trading practices, and haläl food and finance among Muslim countries and communities across the globe. Standardisation in all the material aspects of the halāl industry should naturally take its cue from scriptural sources that constitute the basis of our efforts for uniformity and coordination throughout the Muslim world.

The fiqh discourse essentially elaborates the textual guidelines on haläl and harām, which also have devotional (ta'abbudī) features that go beyond common rationality. To promote uniformity in halāl standards we propose the following:

- With regard to the halāl/mubāh, and also the makrūh and the mandūb, greater uniformity and standardisation in the halāl industry may be attempted by recourse to the principle of selection (takhayyur) and by singling out among the various rulings of the madhăhib one that may be most suitable for that purpose. As an accepted method of Islamic jurisprudence, takhayyur is premised on the recognition that the leading schools of Islamic law have accepted one another as equally valid interpretations of the shari 'ah, which evidently offers potential for greater harmony and unification among them.

- Another method of selection we propose is the patching up (talfiq) of certain aspects of the rulings of different schools or jurists with a view towards amalgamating them into a single formula. Talfiq differs from takhayyur in that the latter selects the ruling as it is of a different madhhab to that of one's own, whereas talfiq attempts to combine certain parts of different rulings/ interpretations into a single formula for the purpose of implementation. ${ }^{47}$

- The setting up of an authoritative shari ${ }^{-} a h$ advisory council we propose should ideally bring together a group of learned figures of standing, and which is internally diversified so that its deliberations, advice and Fatwa are informed by the madhähib, countries and cultural zones of the global ummah. This should also include representation from Muslim minorities in the West.

- A set of procedural guidelines should be formulated for rule-making purposes, and plans should be drawn up that envisage high-level media impact and market penetration.

- We also propose that proactive measures for standardisation of halāl practices should be taken by governments. A brief reference is also in order to an aspect of Islamic jurisprudence that enables the ruling authorities ( $u l \bar{\imath}$ ' $l$-amr) to raise the mandūb into an obligatory command, or a makrūh into a prohibitive rule, regulate certain aspects of mubāh, and even make a suitable ruling on doubtful matters - if such would be to the manifest mașlahah of the people. This is an aspect of what is known as sharī'ah-oriented policy, or siyāsah shar 'iyyah, which is a recognised principle of Islamic public law. The lawful authorities 
are thus empowered to introduce laws and formulate policies that secure the people's best interests in the light of prevailing circumstances.

- There is a need to form a research unit (or units) that brings together researchers in shari 'ah studies, food sciences, market specialists, and social scientists who can conduct research on market particularities, and the customs and cultures of the various countries and regions of the world. The unit can then submit recommendations to the central $\operatorname{sharl~}^{-} a h$ advisory council and the marketing sections of the halāl industry.

- Standardisation in the halāl industry should also be informed by the approved mores and customs of Muslim communities. Since people's likes and dislikes in foodstuffs and marketing practices are influenced by a variety of factors, including climate, soil characteristics and even geographical proximity to other cultures, all of this may need to be taken into consideration in one's quest for standardisation in the halāl industry. These levels of diversity and variation are not always self-evident and may need to be verified. Hence we need to enrich our efforts by research into the customary practices and predilections of countries and regions, as well as by setting in place consultative decisionmaking mechanisms that are duly informed by scientific and sociological research.

\section{Notes}

1. The reason for this diversity of terminology may be due to a degree of sensitivity that the Qur'ān attaches to the subject and the message it conveys is that pronouncing the haläl and harām is the prerogative only of God the Most High, as I shall elaborate. A slight difference in the meaning of these terms may also be relevant to note: whereas $m u b \bar{a} h$ and $j \bar{a}$ ' $i z$ refer to something over which the shari ${ }^{-} a h$ is totally neutral, haläl often implies a degree of purity in the context particularly of foodstuffs, and may as such imply preference that is not totally neutral.

2. The Arabic expressions used for mubāh are: lā ithma, la junāha, lā ba'sa, lā yu'akhidhukum Allāh etc.

3. The Arabic version is: al-aṣlu fì'l-ashyā' al-ibāhah hattā yadullu al-dalīl 'alā al-tahrīm. Cf., Jalāl al-Dīn al-Suyūṭị, al-Ashbāh wa 'l-nażā 'ir (Beirut: Dār al-Kutub al- 'Ilmiyyah, 1983/1403AH), 60. A legal maxim normally consists of an abstract and epithetic statement of a figh position based on the overall reading of available evidence in the Qur'ān and hadīth. By way of explanation, al-Suyūțī raises the question as to the permissibility for human consumption, for instance, of giraffe saying that the jurists have not taken no position on this and it is therefore haläl in the light of the said maxim and also the fact that giraffe is not a predatory animal.

4. Yūsuf al-Qaraḍāwī, al-Halāl wa 'l-harām fì'l-islām (Beirut: al-Maktab al-Islāmī, 1994/1415AH, 15th ed.), 23; idem, Bay 'al-murābahah li'l-ämir bi'l-shirā' (Cairo: Maktabah Wahbah, 1987/1407AH, 2nd ed.), 13. A sound (șhịhh) hadīth is defined as a hadīth with an unbroken isnād (chain of transmitters) all the way to the Prophet or a Companion, consisting of upright persons who possessed retentive memories and whose narration is not outlandish $(s h \bar{a} d h d h)$ and it is free of both obvious and subtle defects ( 'ilal). Cf., Mohammad Hashim Kamali, A Textbook of Hadith Studies (Leicester: The Islamic Foundation, 2005), 139.

5. See for details, Wahbah al-Zuhaylī, al-Fiqh al-islāmī wa adillatuh (Damascus: Dār al-Fikr, 1989/1409AH, 3rd ed.), 3:510f. 
6. Cf., Mohammad Hashim Kamali, Principles of Islamic Jurisprudence (Cambridge: Islamic Texts Society, 2003), 429.

7. Ibid., 429.

8. Abū Isḥāq Ibrāhīm al-Shāțibī, al-Muwāfaqāt fì ușūl al-ahkkam, ed. Muḥammad Ḥasanayn Makhlūf (Cairo: al-Mațba ah al-Salafiyyah, 1920/1341AH), 1:140f; Wahbah al-Zuhaylī, Ușūl al-figh al-islāmì (Damascus: Dār al-Fikr, 1986/1406AH), 86.

9. Cf., al-Qaraḍāwī, al-Halāl wa'l-ḥarām, 15; Muhammad 'Uthman Shābir, al-Qawā'id al-kulliyyah wa'l-ḍawābiț al-fiqhiyyah fì'l-sharī ah al-islāmiyyah (Amman: Dār al-Nafâ'is, 2006/1426AH), 324; Kamali, Principles, 421.

10. The qur'ānic prohibition of pig meat represents a continuation of the Judaic tradition. Similarly the negative view of the Islamic tradition toward dogs is attributed to the fact that the canines were often seen as carriers of rabies and best kept at a safe distance.

11. Ibn Mājah al-Qazwīn̄̄, ed. Muḥammad Fu'ād 'Abd al-Bāqī, Sunan Ibn Mājah (Beirut: Dār al-Kutub al- 'Ilmiyyah, 1987/1407AH), hadīth no. 3,367; al-Qaraḍāwī, al-Halāl wa'l-ḥarām, 23.

12. Cf., al-Qaraḍāwī, al-Halāl wa 'l-harām, 34; Shābir, al-Qawā'id, 324.

13. Cf., al-Qaradāwī, al-Halāl wa 'l-harām, 37-8. Minor exceptions exist here in the case, for instance, of riba ' (usury) that a Muslim may practise, in relationship to a non-Muslim. But this too, is a disputed opinion and some jurists consider it invalid, while others say that only if the non-Muslim is a harbi and resident of a hostile country.

14. Ibid., 34. Al-Qaraḍāwī illustrates this by say calling casino dance as a form of art, or $r i b \bar{a}$ ' as profit.

15. Cf. Wizārat al-Awqāf wa'l-Shu'ūn al-Islāmiyyah, al-Mawsū 'ah al-fiqhiyyah (Kuwait, 1993/1414AH, 4th ed.), 5:125.

16. Ibid.

17. Muslim, Mukhtașar Șah̄ịh Muslim, ed. Muhammad Nāṣir al-Dīn al-Albānī (Beirut: Dār al-Maktab al-Islāmī, 1987), 342, hadīth no. 1,262.

18. 'Alā' al-Dīn al-Kāsānī, Badā' 'i ' al-șanā 'i ' fì tartīb al-sharā' 'i ' (Beirut: Dar al-Kutub al- 'Ilmiyyah, 1986/1406AH, 2nd ed.), 5:114; al-Zuhaylī, al-Fiqh al-islāmī, 3:5.

19. The substance of this is also conveyed in a hadith: "It is forbidden to take the property of a Muslim without his consent.” See Abū Bakr 'Abd al-Raḥmān b. al-Ḥusayn al-Bayhaqī, al-Sunan al-kubrā, ed. M. 'Abd al-Qādir 'Ațā' (Mecca: Maktabah Dār al-Bāz, 1987/1407AH), 6:100, hadīth no. 11,325. We also read in another hadith: "You and your property both belong to your father." See Muhammad b. 'Abd Allāh al-Khațīb al-Tabrīzī, Mishkāt al-mașābīh, ed. Muhammad Nāṣir al-Dīn al-Albānī (Beirut: Dār al-Maktab al-Islāmī, 1979/1399, 2nd ed.), hadìth no. 3,354.

20. Muslim, Mukhtașar Șahīh Muslim, 253, hadìth no. 956.

21. al-Qaraḍ̄̄wī, al-Halāl wa 'l-harām, 37.

22. al-Tabrī̄ì, Mishkāt, 2:845, hadīth no. 4,046.

23. BSE stands for bovine spongiform encephalopathy. See more on this in Richard C. Foltz, Animals in Islamic Tradition and Muslim Countries (Oxford: Oneworld Publications, 2006), 118. Foltz thus informs us on the same page that "Middle Eastern countries now import much of their meat from places such as New Zealand and that factory farming presents considerable difficulties in verifying whether meat is halāl."

24. The view is attributed to Mazhar Hussaini, Director of the North American Halal Foundation, quoted in Foltz, Animals, 118.

25. The Arabic version reads "idhā ijtama 'al-halāl wa'l-harām, ghuliba al-ḥarām”; cf., Shābir, al-Qawa' 'id, 325. Interestingly enough, al-Qarad̦āwī does not refer to this maxim in his brief discussion of "avoidance of the doubtful - ittiqa al-shubhāt", which is perhaps not accidental, due to another line of evidence that advises taking that which is the easier course and brings facility and relief. This may why al-Qaraḍāwī subsumes the issue under the rubric of sadd al-dharā' $i$ :

26. Cf., Shābir, al-Qawā'id, 326-8.

27. See for details Muhammad Abū Zahrah, Ușūl al-fiqh (Cairo: Dar al-Fikr al- 'Arabī, 1958/1366AH), 34; Kamali, Principles, 424.

28. Cf., Kamali, Principles, 426.

ICR 1.4 Produced and distributed by Pluto Journals ICR.plutojournals.org 
29. Thus according to one hadith "The Prophet proscribed eating the flesh of a jallalah camel", and according to another "The Prophet proscribed drinking the milk of a jallalah". Both hadìths are quoted in Sunan Daraqutnī and Sunan Abū Dawud, respectively, and quoted in Wizārat al-Awqāf wa'l-Shu'ūn al-Islāmiyyah, al-Mawsū 'ah al-fiqhiyyah, 5:149.

30. al-Kāsān̄̄, Badā' 'i', 5:39-40; Muhammad Amīn b. 'Ābidīn, Hāshiyah radd al-mukhtār 'alā durr al-mukhtār (Cairo: Dār al-Fikr, 1979/1300AH), 5:194.

31. Cf., al-Zuhaylī, al-Fiqh al-islāmī, 3:667.

32. Cf., Wizārat al-Awqāa wa'l-Shu'ūn al-Islāmiyyah, al-Mawsū' ah al-fiqhiyyah, 5:152.

33. Ibid., 5:153.

34. Ibid., 5:155.

35. Cf., Ibn Rushd, Bidāyat al-mujtahid (Beirut: Dār al-Qalam, 1988), 1:329; al-Zuhaylī, al-Fiqh al-islāmī, 3:663-4.

36. See for details Kamali, Principles, $419 \mathrm{f}$.

37. Foltz, Animals, 27.

38. See for details al-Qaraḍāî̀, al-Halāl wa 'l-harām, 61; al-Zuhaylī, al-Fiqh al-islāmī, 3:659.

39. al-Qaraḍāwī, al-Halāl wa'l-harām, 61-2.

40. Ibn Rushd, Bidāyat al-mujtahid, 1:325f; al-Zuhaylī, al-Figh al-islāmī, 3:661-3.

41. Ibn Rushd, Bidāyat al-mujtahid, 1:327-8; al-Zuhaylī, al-Fiqh al-islāmī, 3:663-4; al-Qaradāwī, al-Halāl wa'l-harām, 55f.

42. Abū Dawud, Sunan Abu Dawud, Engl. tr. Ahmad Hassan (Lahore: Sh. Ashraf, 1984), 2:1149, hadìth no. 411. See for a discussion also, Kamali, Principles, 153.

43. al-Qarad̄āwī, al-Halāl wa'l-haram, 51-2.

44. Ibid., 51.

45. Cf., Kamali, Principles, 369; Shābir, al-Qawā'id, 244 f.

46. The Mejelle, Being an English Translation of Majallah el-Ahkam-i Adliya and a Complete Code of Islamic Civil Law, tr. C.R. Tyser et al. (Kuala Lumpur: The Other Press, 2003, repr.), Art. 36. The Mejelle records several other legal maxims on custom, including "the use of men is evidence according to which it is necessary to act" (Art. 37). See for further details Kamali, Principles, 371.

47. See for details on takhayyur and talfĩq, Mohammad Hashim Kamali, "Sharīah and Civil Law: Toward a Methodology of Harmonisation”, Islamic Law and Society 14 (2007), 406-11. 